NASA Contractor Report 198531

\title{
Chemical Microthruster Options
}

Wim de Groot and Steve Oleson

NYMA, Inc.

Brook Park, Ohio

October 1996

Prepared for

Lewis Research Center

Under Contract NAS3-27186

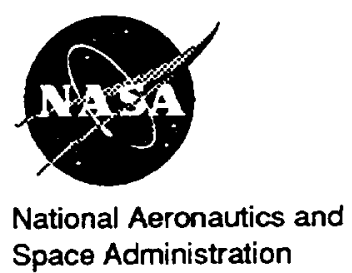


Trade names or manufacturers' names are used in this report for identification only. This usage does not constitute an official endorsement, either expressed or implied, by the National Aeronautics and Space Administration. 


\title{
Chemical Microthruster Options
}

\author{
Wim de Groot " and Steve Oleson" \\ NYMA, Inc., Engineering Services Division \\ Brookpark, OH
}

\begin{abstract}
Chemical propulsion systems with potential application to microsatellites are classified by propellant phase, i.e. gas, liquid, or solid. Four promising concepts are selected based on performance, weight, size, cost, and reliability. The selected concepts, in varying stages of development, are advanced monopropellants, tridyne ${ }^{n \mu}$, electrolysis, and solid gas generator propulsion. Tridyne ${ }^{\text {Tu }}$ and electrolysis propulsion are compared vs. existing cold gas and monopropellant systems for selected microsatellite missions. Electrolysis is shown to provide a significant weight advantage over monopropellant propulsion for an orbit transfer and plane change mission. Tridyne $^{T M}$ is shown to provide a significant advantage over cold gas thrusters for orbit trimming and spacecraft separation.
\end{abstract}

\section{Introduction}

The desire to reduce the size and weight of satellites, especially those planned for future NASA missions, creates a renewed interest in microthrusters for trajectory corrections and attitude control. Previously, the most important parameters in the choice of microthruster type were the performance and reliability. With the current trend toward small inexpensive satellites, however, cost, size, and weight have been added as dominant considerations. Both reliability improvement and reduction in size, weight, and cost can be accomplished by means of reduced system complexity. These enhancements, however, often occur at the expense of performance. A standard simple system for microthrust propulsion is the cold gas jet. It typically consists of nitrogen pressurized to approximately $21 \mathrm{MPa}$ and, depending on the thrust level, provides a maximum specific impulse $\left(l_{s p}\right)$ of $76 \mathrm{~s}$ in a blowdown mode.

An excellent review of the status of microthrust technology in the mid 60s was given by Sutherland and Maes. ${ }^{1}$ Some of the technology items have since fallen out of favor, such as radio isotope heating of the working fluid to enhance thruster performance. Other technologies, not sufficiently developed for serious consideration at the time, could present attractive choices for some missions. Among such thrusters are gas-solid hybrid thrusters and gas generator type thrusters.

The term microthrust refers to the thrust level and not to the physical size of the thruster. Typically, rockets with a thrust between $10^{-6}$ and $10 \mathrm{~N}$ fall within this class. Depending on the type of energy that is supplied to provide the thrust, microthrusters can be classified as chemical, electrical, or electro-chemical.

Recent developments in electronics and energy storage have made the application of electric thrusters, with their high specific impulse, more attractive in the microthrust region.' In many applications where high impulse bits are required or where electric power is scarce or not available (missions to the outer solar system), chemical systems are an attractive option. This paper only covers the chemical class. Electrolysis is included because the nature of the energy provided to the working fluid to generate thrust is chemical.

\footnotetext{
- Senior Propulsion Specialist, Senior Member AJAA

"Research Engineer, Member AIAA

${ }^{\mathrm{T}} \mathrm{M}$ Tridyne is a registered Trademark of Rockwell International/Rocketdyne Division.
} 
Chemical microrockets can be classified variously. The clearest distinction, analogous to that of Sutherland et al., ${ }^{1}$ is by the phase in which the propellant is stored. These are referred to as solid, liquid, and gaseous rockets, as well as some hybrid systems, where the fuel and oxidizer appear in different phases.

In general, solid propellant systems represent a minimum system dry weight and complexity as the result of the absence of high pressure tanks, propellant lines and valves. The need for a thermal source to initiate combustion or decomposition will slightly reduce this weight advantage. A disadvantage of solid propellant thrusters is the difficulty in accurately controlling the thrust and cycling.

Vaporizing liquid propeliant rockets also do not require high pressure tankage and propellant lines, but are more complex than solid propellant rockets because of the need for phase separation between liquids and gas, and, for applications with a lack of inertia, the need to restrain the liquid (slosh). Gaseous systems carry the highest penalty in system weight, but will sometimes be needed to deliver the response and/or thrust level that the solid and liquid systems lack with great system simplicity.

All three propellant types produce thrust based on the same principle. A gas is generated inside a chamber with sufficient pressure to choke a nozzle. To provide an acceptable $I_{\text {sp, }}$ the molecular weight of the gas needs to be sufficiently low for a significant acceleration in the nozzle. As an addition to each of these three systems, an electrical heater can be provided (resistojet) to heat up the gas in order to provide a higher acceleration and higher specific impulse while adding only slightly to system complexity. The heater system requires a power supply, which might be prohibitive for specific applications.

The propulsion system selection requires a detailed analysis of each mission. A mission that requires a large $\Delta V$ for trajectory corrections, for example, will require a system that can provide a large total impulse. This clearly favors a higher specific impulse thruster. Response time and thrust level are less important for such missions. In a system designed for attitude control, response time becomes more important. If attitude control needs to be provided over a period of several years, a high total impulse is required favoring a high specific impulse thruster. This often implies, however, that system complexity increases as well as the weight and size, and that reliability issues become important.

Propellant phase has been chosen as the primary classification for this paper. Problems associated with propellant management systems, such as phase separation in the absence of gravity, slosh, and vaporization, are largely similar across each class of propellants. A review is given of the currently available propulsion options including propellant properties and thruster performance characteristics. From the available systems, four promising concepts for microthrust propulsion are selected for further analysis. Example mission analyses for two of these concepts, tridyne ${ }^{\text {nd }}$ and electrolysis, has been done. A substantial improvement in weight, size, cost, and performance over currently available commercial propulsion systems is shown.

\section{Types of microthrust systems}

Each propellant class (gas, liquid, solid) represents a number of different propulsion concepts. In this section, concepts in each class are summarized, roughly in order of complexity. The advantages and disadvantages of each type are listed, without details on specific mission applications. Pertinent properties of propellants, such as chemical composition, specific density, and product composition are listed by phase in Table 1. Projected performance characteristics for the described propulsion systems are listed in Table 2.

In order to obtain a more complete comparison of the different concepts, other criteria were taken into consideration and will be discussed. Some are quantitative, such as duty cycle, pulse response, cost, and development status. Others are more subjective, e.g. safety and reliability and will not be addressed here. 


\section{GASEOUS PROPELLANTS}

Cold Gas. A cold gas (nitrogen or helium) is stored at high pressure ( $21 \mathrm{MPa})$. A regulator brings the pressure down to the desired pressure (0.1-1 $\mathrm{MPa}$ ) after which the gas is fed by means of check valves to a nozzle. The advantages are safety, low cost, rapid response, and a simple system with high reliability. Although the thrusters are low in weight, the overall system weight will be moderate due to the need for high pressure tanks and a distributed feed system. The system is volumetrically inefficient due to the large tankage needed for gaseous storage. Typical thrust levels range from 0.005 to $250 \mathrm{~N}^{3}$ Specific impulse depends on thrust level and varies from 45 to $75 \mathrm{sec}$ at $295 \mathrm{~K}$ for a nozzle area ratio of 100 , due to increasing nozzle losses for decreasing thruster size. This system has been used extensively to provide spacecraft and launch vehicle attitude control (ACS) and divert propulsion, which is used to change a vehicle's direction. ${ }^{3}$

Tridyne $^{\text {m }}$ propellants. A tridyne ${ }^{\text {nd }}$ system consists of a nondetonable mixture of hydrogen, oxygen, helium, and/or nitrogen, which is passed over a catalyst bed to release energy. ${ }^{4}$ The released energy heats up the bulk helium or nitrogen gas which is expelled through a nozzle creating thrust. Typical chamber operating temperature and pressure are $1100 \mathrm{~K}$ and $0.07-0.35 \mathrm{MPa}$, respectively. Thrust levels of $0.04 \mathrm{~N}$ have been obtained with a specific impulse of 138 sec for an area ratio of 100 . The advantages are a higher specific impulse than cold gas systems and that the system weight compares favorably with cold gas thrusters for a given total impulse. At the same time, all the simplicity of a cold gas thruster is retained. Tridyne ${ }^{\mathrm{TM}}$ systems have not been used as flight thrusters, although they would be applicable to spacecraft using cold gas propulsion.

Gaseous bipropellants. Gaseous fuel and oxidizer are injected, mixed, and reacted in the combustion chamber and exit through the nozzle. Advantages of these systems are the high performance (with oxidizers such as oxygen or fluorine $\left(\mathrm{O}_{2} / \mathrm{F}_{2}\right)$, and fuels such as methane, ethylene, or hydrogen $\left.\left(\mathrm{CH}_{4} / \mathrm{C}_{2} \mathrm{H}_{4} / \mathrm{H}_{2}\right)\right)$ with a theoretical $\mathrm{I}_{\mathrm{sp}}$ of 350 $400 \mathrm{sec}$ for an area ratio of 100 . There is no need for an external pressurization system and there are no freezing or boiling point difficulties. Additional advantages include the absence of propellant slosh, liquid/gas separation problems, and potentially simple injector design. Disadvantages of the use of gaseous bipropellants in low thrust applications include the poor mixing efficiency due to short residence time in the combustor, material incompatibility with oxidizer, and high temperature material issues. $^{5}$ Mixing problems limit the lower level of thrust that can reliably be obtained to $0.1 \mathrm{~N}$. The low propellant density requires relatively large tankage. As a result, gaseous bipropellants are limited to moderate total impulse missions. A higher degree of complexity than the cold gas thrusters is inherent and this reduces reliability. Poor mixing can cause a pulse to pulse variation in both magnitude and time history of thrust pulses, which is undesirable for many applications.

\section{LIQUID PROPELLANTS}

Vaporizing liquids. These thrusters use liquid propellants that can be stored over a period of years. The liquid vaporizes into a low molecular weight vapor (water, ammonia or propane) with a high enough vapor pressure to provide acceptable performance. Heat of vaporization is supplied by the bulk liquid, whose temperature can be maintained from spacecraft structure or using electric heaters. A theoretical $I_{s p}$ for ammonia of $100 \mathrm{sec}$ can be projected at $293 \mathrm{~K}$ with a nozzle area ratio of 50 . Thrust levels vary from $10^{-4}-0.5 \mathrm{~N}^{7}$ Liquid systems are more complex as the result of a liquid control mechanism, a vaporizer, propellant lines, and valves. The separation of gas and liquid in the absence of gravity or satellite spin is an additional concern. In some cases, a separate plenum chamber is used for vapor storage. Thrust decay will occur for liquid vapor thrusters because vaporization typically does not occur as rapidly as the propellant is expelled. Because the heat of vaporization is obtained from the liquid, the pressure decay during long periods of thrust depends on the ratio of thrust to propellant mass and to the power input if an external source is used to provide heat.

Liquid Monopropellants. A liquid propellant is passed through a catalyst bed. It decomposes into a high pressure, high temperature gas, which is expelled through a converging-diverging nozzle. The majority of monopropellant systems use hydrazine 
$\left(\mathrm{N}_{2} \mathrm{H}_{4}\right)$, although hydrogen peroxide $\left(\mathrm{H}_{2} \mathrm{O}_{2}\right)$ was used extensively in the past. Products species are hydrogen, nitrogen, water, and ammonia. Monopropellant performance at microthrust levels is slightly lower than bipropellants but with greater reliability and at lower complexity and cost. Thrust levels are upwards of $0.1 \mathrm{~N}$ with an $\mathrm{I}_{\text {sp }}$ of 206-235 $\mathrm{sec}$ for area ratio of $100 .^{7}$ Other advantages are a fast response $(<10 \mathrm{msec})$ and unlimited restart capability. Because catalyst deterioration is a function of propellant flowrate, an added benefit at very low thrust levels is the excellent catalyst durability. A disadvantage is the toxicity (hydrazine) and/or volatility (hydrogen peroxide) of the propellants, which adversely affect the cost by an increase in required safety procedures in handling the propellants and servicing the propulsion system. Alternative propellants are being investigated that provide equal or better performance which are much more benign. ${ }^{8}$ Liquid Bipropellants. Bipropellant engines with liquid phase injection operate at thrust levels above $1 \mathrm{~N}$. Propellant combinations are nitrogen tetroxide/hydrazine $\left(\mathrm{N}_{2} \mathrm{O}_{4} / \mathrm{N}_{2} \mathrm{H}_{4}\right)$ or nitrogen tetroxide/monomethyl hydrazine $\left(\mathrm{N}_{2} \mathrm{O}_{4} / \mathrm{MMH}\right)$. Specific impulse of flight type thrusters is typically $295 \mathrm{sec}$ for a 100:1 area ratio. At lower thrust levels, injector problems occur as the result of the low flow rates. Mixing is typically not well controlled and orifices tend to plug. Other problems at microthrust levels are low reliability and poor pulse performance. Liquid bipropellant rockets cover the range of higher thrust and higher total impulse missions.

A different type of liquid bipropellant thruster employs vaporizing liquid propellant. Injector and orifice problems associated with the liquid phase are absent. Some vapor control is needed to obtain desired mixture ratios, and gas-liquid separation technology is needed in the absence of satellite spin. These types of thrusters have a high degree of complexity and a low reliability. Some propellants are not hypergolic in the liquid phase but are hypergolic in the vapor phase, such as chlorine trifluoride $\left(\mathrm{ClF}_{3}\right)$ as oxidizer and methyl amine $\left(\mathrm{CNH}_{5}\right)$ as fuel. Both propellants have acceptable vapor pressure for injection. Thrust levels for these types are from 1 - $50 \mathrm{~N}$. Theoretical specific impulse is $336 \mathrm{sec}$. The major drawback of these systems is the volatility and toxicity of the propellants. $\mathrm{CIF}_{3}$ is extremely damaging to skin and eyes and reacts violently with organic materials. Cleanliness requirements for storage are stringent. Safety problems and the increased cost as the result of handling and servicing make these type of propellants unattractive for microthrust applications.

\section{SOLID PROPELLANT}

Solid gas generator compounds that decompose into low molecular weight gases are used in microthrust applications. Gas generator compounds can be classified into subliming, photo-decomposing, and exothermally decomposing materials. Subliming compounds vaporize by absorbing heat from the bulk propellant or from the spacecraft. Photo decomposing materials react under exposure of ultraviolet (UV) radiation by absorbing light from the sun or UV source. Exothermic compounds decompose by absorbing energy provided by the breakup of the propellant itself.

Subliming thrusters. Subliming thrusters use solid propellants that can be stored over a period of years. Two types of subliming solid thrusters have been considered, valveless and valved. In both types, propellants sublime into low molecular weight vapor with a high enough vapor pressure to provide acceptable performance at workable propellant feed system conditions and nozzle size. Types of propeliants are usually carbonates $\mathrm{X}\left(\mathrm{HCO}_{3}\right)$ or carbamates $\left(X\left(\mathrm{CO}_{2} \mathrm{NH}_{2}\right)\right)$ subliming into $\mathrm{NH}_{3}, \mathrm{CO}_{2}$, and $\mathrm{H}_{2} \mathrm{O}$. ${ }^{\circ}$ Subliming thrusters are the simplest microthrusters from a systems perspective. As the result of the low storage pressure and lack of propellant lines and valves, the overall system weight is very small and the reliability is very high. Additional advantages are its overall simplicity and a high propellant bulk density, resulting in a reduced system size. Disadvantages are the low thrust level, low performance and limited duty cycle. Additional problems occur due to recondensation of the gaseous products inside the propellant lines unless propellant lines are kept at sufficiently high temperature.

In valved versions, ${ }^{11}$ solid propellants are stored in solid-vapor equilibrium conditions 
in a closed light-weight tank. A valve in the propellant feed line from the tank to the nozzle controls the thrust. Opening the valve produces thrust by expulsion of the vapor through the nozzle. The solid sublimes to make up for the lower vapor pressure. Heat of sublimation is provided by the bulk propellant, which needs to be thermally controlled by heat from the spacecraft structure or external heater. Theoretical $I_{s p}$ of $80-85 \mathrm{sec}$ for an area ratio of 100 are possible with simple system design. Because the vapor pressure determines the thrust, the thrust will decay during a pulse depending on how fast the solid will replace the vapor. Thrust levels are low, but pulse response is high.

A typical valveless thruster consists of a solid propellant inside a chamber with an open connection to the nozzle. Between uses, the propellant is self cooled and the vapor pressure is negligible. When needed, sunlight or an extemal heat source sublimes the solid, creating a vapor pressure that provides thrust. Thrust levels from $10^{-3}-10^{-1}$ $\mathrm{N}$ and specific impulse from $50-70 \mathrm{sec}$ are low, system response is slow, and the power needed for heating the propellant is $2-3 \mathrm{~kW}$ per $N$ thrust.

Photochemical rocket. UV light $(<2537$ A) from the sun or from an artificial source causes the propellant to decompose, providing thrust. ${ }^{12}$ The propellant must have a useful decomposition rate. Some such propellants are the azides (ammonium azide $\mathrm{NH}_{4} \mathrm{~N}_{3}$ ), oxalates, permanganates, perchlorates, and organic solids such as $1,3,5,7$ tetranitro-1,3,5,7 tetrazacyclooctane (HMX). Typical products for the ammonium azide are ammonia $\left(\mathrm{NH}_{3}\right)$ and nitrogen $\left(\mathrm{N}_{2}\right)$ with molecular weight of 22.5. Advantages are a very low system weight, reliability and long life. Theoretical performance calculations give an $I_{s p}$ of $130 \mathrm{sec}$ at a thrust level of $10^{-4} \mathrm{~N}$. Depending on the propellant type, the response can be in the order of msec.

A major disadvantage of all subliming thrusters is the tendency of the vapor to condense or solidify inside the propellant lines or nozzle. This is especially true for carbon biproducts. It can cause a deterioration of performance and limit life. Disadvantages of the azide based propellants are the hazards involved. Ammonium azide is a strong bloodpressure depressant, and needs to be handled carefully. All azides need to be stored away from water and carbon dioxide, as these substances tend to decompose the azide, forming hydrazoic acid, a strong explosive, as a byproduct.

Performance of subliming thrusters can be improved by heating the gases just upstream of the nozzle (resistojet). This requires a more complex system. A theoretical performance improvement from $130 \mathrm{sec}$ to $245 \mathrm{sec} I_{\mathrm{sp}}$ can be obtained for a photochemical microthruster using ammonium azide as propellant, when the products are heated to $1100 \mathrm{~K}$. This option is not viable for carbon containing vapors because carbon deposits tend to accumulate inside the heating element and cause arcing to occur.

\section{HYBRID PROPELLANT}

A hybrid thruster typically consists of a solid fuel grain (hydroxyl-terminated polybutadiene (HTPB) or polyethylene) inside a combustion chamber through which a liquid oxidizer ( $\left(\mathrm{LOX}, \mathrm{H}_{2} \mathrm{O}_{2}\right.$ ) flows. ${ }^{13,14}$ Advantages are that these devices are throttleable, restartable, and have a specific impulse close to storable liquid bipropellants. They are also relatively safe from an energetic point of view (virtually nondetonable). Other advantages are the small volume (due to high propellant density), low cost, and the simple system design (i.e. a single liquid). Projected specific impulse is $290 \mathrm{sec}$ for a $400 \mathrm{~N}$ thrust engine. This type of device has not been considered for smaller applications to date.

\section{ELECTROCHEMICAL}

Electrolysis. In electrolysis systems, a liquid (usually water) is decomposed by means of an electric current into its elemental gases. These gases are used as propellant in a standard gas/gas chemical thruster. Advantages include high theoretical specific impulse (390-425 sec), low weight as the result of absence of pressurization system, and a high propellant storage density. Rapid pulse response and a wide range of thrust levels and impulse bits can be achieved. Additional advantages lie in the dual use applicability of the electrolysis unit. As the 
result of the reversibility of the electrolysis principle, the system can be used as a fuel cell to provide power for cases where solar arrays are not sufficient. Solar energy can be stored in the electrolysis products whenever there is excess power available. This energy can be recovered when needed by reversing the electrolysis process. By replacing the batteries with an integrated electrolysis/fuel cell unit, large weight savings can be obtained for specific missions. ${ }^{15}$

Disadvantages are the limited duty cycle, caused by the slow electrolysis process, the need to dry the electrolysis gases, and the need for a specialized electrolysis cell. The overall system complexity is high relative to other candidates. Reliability of the electrolysis system is high, however, as the result of a long history of use in submarine and commercial applications.

\section{Promising Concepts for Microthrust Application}

Each of the above described chemical propulsion concepts can be adapted for microsatellite propulsion. The selection process of an optimum propulsion system for specific applications requires mission analysis. Some simple guidelines can be used, however, to downselect to a few concepts, without considering specific missions. Major evaluation criteria are weight, size, cost, reliability and performance. Other considerations include propellant characteristics (toxicity, volatility, storability), system complexity, development status, operable thrust levels, dual mode adaptability, need for thermal control of stored propellants, and spacecraft contamination by exhaust products.

For the purpose of this paper, advanced (liquid) monopropellants, tridyne ${ }^{\mathrm{TM}}$ propulsion, electrolysis, and exothermic decomposing solid (gas generator) propulsion are described in more detail. Cold gas thrusters and state-of-the-art monopropellant thrusters are used as a baseline for comparison, because they are simple, reliable and are in common use.

Projected ranges of thrust versus specific impulse for the chosen systems are shown in Figure 1. The ranges indicated are a general guideline for applicability. For typical missions, important parameters are duty cycle (percentage of time the thruster can be operated), minimum impulse bit size and repeatability, and steady state performance.

A simple schematic for each of the systems described in the previous section is shown in Figure 2. An attempt was made to account for all the components required for operation as well as to suggest a potential propulsion system configuration. Pressure transducers and thermocouples have been left out of the schematic for clarity but are included in the weight analysis that follows.

Advanced Monopropellants are targeted to fill the high thrust, high total impulse requirements of microthrust applications. Propellants currently under investigation were originally developed as gun propellants. The most common oxidizer in the proposed monopropellant mixture is HAN (hydroxyl amine nitrate), a salt which is dissolved, together with a fuel, in water. One of the fuels investigated is TEAN (triethyl amine nitrate). The theoretical specific impulse of a HAN/TEAN mixture with $20 \%$ water is nominally $253 \mathrm{sec}$. Projected thrust levels are from $0.4 \mathrm{~N}$ to 500 $N$. Below this lower limit, problems are expected with the low flowrate over the catalyst bed. Problems with combustion at rocket chamber pressures below $3 \mathrm{MPa}$ forced the search for new fuels such as DEHAN (diethylhydroxyammonium-nitrate).

Water in the advanced monopropellants acts as a diluter to prevent explosive hazards. The lowest acceptable water percentage is determined by safety, typically $10 \%$. A higher water percentage implies a lower performance. For the propellant combinations currently under investigation, a typical water percentage is $20 \%$. This higher percentage will reduce performance somewhat but will also cause the decomposition in the catalyst to occur at lower temperatures, avoiding critical high temperature catalyst and combustor material issues.

Potential advantages over hydrazine monopropellants are the higher anticipated performance, higher density, and the reduction of thermal control of the 
propellants (HAN/TEAN freezes at $200 \mathrm{~K}$, hydrazine freezes at $273 \mathrm{~K}$ ). More importantly, the non-toxic nature of the propellants eliminates costly loading and handling procedures required for hydrazine. The range of thrust levels and total impulse are projected to be similar to state of the art monopropellants. Monopropellant rockets in general perform better at higher duty cycles and at higher thrust levels. As a result of the good specific impulse, higher total impulse missions usually require monopropellants.

A potential single string system schematic is shown in Figure 2. A blowdown system is used for its simplicity and minimum weight. The liquid monopropellant is stored in a high pressure tank, separated from the pressurizing gas by means of a diaphragm. The pressurizing gas feeds the monopropellant to the thruster via propellant lines. A pyrovalve is used to prevent propellant loss for long storage times and to activate the propulsion system when needed. A filter is used to prevent particles from clogging the injector or contaminating the catalyst bed. A latch valve controls the propellant flow to the catalyst bed. The propellant passes through the catalyst bed where it decomposes into high temperature products. The gas is expelled through the nozzle, providing thrust.

Further details on the status of advanced monopropellant development are given in Reference 8.

Tridyne $^{\text {TM }}$ Propellants. Tridyne ${ }^{\text {TM }}$ propellants are targeted to compete with cold gas jets for a wide range of applications, increasing the envelope of total impulse that can be covered with a simple, single gas. Hydrogen and oxygen are mixed with nitrogen and/or helium as diluent. This gives a nondetonable mixture that, if passed over a catalyst bed, heats up by means of the hydrogen-oxygen reaction. The choice of nitrogen or helium depends on the behavior of the catalyst bed.

A simple single string system schematic is shown in Figure 2. The propellant is stored at a high pressure (21 MPa - $2 \mathrm{MPa}$ ) in a propellant tank. A pyrovalve prevents propellant loss and is used to activate the system. A filter installed in the propellant line clears particles and a latch valve controls the propellant flow rate to the thruster. The propellant passes over the catalyst bed where the exothermal reaction heats up the gas. The products are expelled through a diverging nozzle, providing thrust.

Advantages of the tridyne ${ }^{\text {m }}$ system have been described in the propulsion concept review section. A potential disadvantage is that the impulse bit response is not as rapid as for cold flow thrusters due to the residence time of the propellant in the catalyst bed. Potential problems associated with catalyst deterioration as the result of cracking of the catalyst material during thermal cycling were not considered in this analysis. These problems depend on the propellant flow rate over the catalyst. Lower flow rates are beneficial to catalyst life. Problems can also be reduced by thermal management of the propellant. This may require some power and a slightly more complex system.

Minimum impulse bit available for the Tridyne $^{\mathrm{T}}$ is projected to be larger than for cold gas thrusters. Tridyne th thrusters are expected to operate over the full range of duty cycles, depending upon the thrust level. The applicable range of total impulse is limited as a result of the lower specific impulse as compared to mono- or bipropellant thrusters. The propellant volume required for a large total impulse mission is prohibitive.

Tridyne $^{\text {ru }}$ systems can also be used as pressurization systems for blowdown of liquid monopropellants, bipropellants, or hybrid rockets. ${ }^{16}$

Electrolysis was used in the Gemini and Biosatellite space programs. It is a mature concept that has been refined to provide high performance with the safety inherent in water as propellant and the reliability proved with years of commercial applications. $^{17}$ Measurements on a $0.44 \mathrm{~N}$ thruster showed an experimental specific impulse of $331 \mathrm{sec}$ with a molybdenum combustor. ${ }^{18}$ High temperature combustion chamber materials (such as refractory metals) could improve that number by 20 sec by reduced film cooling needs and enhanced mixing. ${ }^{19}$ 
A simple electrolysis system schematic is shown in Figure 2. Water stored in a light weight tank is fed to the electrolysis unit. Hydrogen and oxygen products from the electrolysis are stored, either in separate tanks, or as pressurizing gas in water tanks. For simplicity and low weight, a blowdown system is used for the propulsion section. Check valves prevent the gases from flowing back into the electrolysis unit. Fitters clean the gases from particles and latch valves control propellant flow to the thrusters.

Electrolysis/fuel cell round-trip electrical efficiencies (electrolysis followed by fuel cell) currently are between $47 \%$ and $66 \%{ }^{17,20}$ Such a system can replace currently used batteries at a great reduction in weight. A carefully designed single string system can provide the energy storage and fulfill many of the on-board propulsion tasks, This unified approach can save substantial weight and reduce overall spacecraft complexity. While recently developed Lithium-Ion batteries have better energy densities than SOA $\mathrm{NiH}_{2}$ batteries, they are still in an early stage of development.

Whether the dual propulsion and power capacity will actually be used depends on the application. For very short discharge times (as in LEO orbit, where the cycle between dark- and sun- cycles is relatively short), batteries have a higher energy density (25 Whr $/ \mathrm{kg}$ for NiCd vs. $12 \mathrm{Whr} / \mathrm{kg}$ for fuel cell). Because the electrolysis/fuel cell is available for propulsion, a weight savings can still result if the battery is replaced.

For missions with increasing discharge times, the weight savings become increasingly large. The energy density of a fuel cell for a solar probe, for example, could exceed $1000 \mathrm{Whr} / \mathrm{kg}$, as opposed to $200 \mathrm{Whr} / \mathrm{kg}$ for the best available Lithium Ion batteries.

The duty cycle of electrolysis units varies depending on the thrust level, the size of the electrolysis cells, and the total power input available. Response is rapid and impulse bits are repeatable. For the blowdown type system that is considered for its simplicity, steady state thrust will decay over time due to the drop in upstream pressure.
Exothermic decomposing solid propellants. Subliming compounds have been exhaustively investigated for utilization in gas generators. Thrust levels obtained depend on the vapor pressure of the subliming compound, usually less than 0.1 $\mathbf{N}$ over a short period of time. The duty cycle depends on the thrust level, but is rather limited because sublimation replaces the expelled gas slowly. As the result of the low specific impulse, only low total impulse missions can be served with subliming solids. Response is only limited by valve opening time. Minimum impulse bit and repeatability are excellent.

A compound has been developed for gas generator applications ${ }^{21}$ that has the potential to be used in decomposing solid rockets with the simplicity of subliming rockets but with a higher projected thrust level, higher $I_{s p}$, higher propellant density, and higher impulse bits. The chemical composition of this heterocyclic compound with ring structure is $\mathrm{C}_{2} \mathrm{H}_{4} \mathrm{~N}_{6} \mathrm{O}_{2}$. The heat of formation is $39.2 \mathrm{Kcal} / \mathrm{mole}$. Theoretical performance of this monopropellant is $\mathbf{2 6 5 . 2}$ sec for area ratio of 100 . The propellant density is $1.86 \mathrm{~g} / \mathrm{cc}$, promising compact packaging. The compound is non-toxic, noncarcinogenic, and does not form fragments or particles during decomposition, and therefore does not present a health hazard. It is also not detonable on impact and not electrostatically sensitive. Primary products are hydrogen, nitrogen, carbon dioxide and carbon monoxide, with an average molecular weight of $21.2 \mathrm{~g} / \mathrm{mole}$. Projected thrust levels vary from 0.001 to $10 \mathrm{~N}$.

Ignition can be accomplished with a diode laser. After ignition, the process is selfsustaining above $0.7 \mathrm{MPa}$ by heat of decomposition. Decomposition can be terminated by a sudden depressurization. Several scenarios can be designed for a restartable solid monopropellant.

A " pill-dispenser" type will place a pill of the compound at the head end of the thruster. A diode laser initiates decomposition. The solid decomposes at $1900 \mathrm{~K}$ and is expelled through a nozzle, providing a fixed impulse bit, determined by the pill size. A second design, shown schematically in Figure 2, consists of a small diameter rod of solid propellant which is pushed with a spring 
mechanism into the chamber through the center of the head end. The diode initiates decomposition. Initially, the decomposing surface area is large and the pressure builds up rapidly, sustaining decomposition. As the surface area decreases and recesses into the head end of the thruster, the mass flow through the nozzle exceeds the mass addition due to decomposition. When the chamber pressure drops below a critical limit, decomposition is terminated. The motor can be restarted by pushing the rod further. Impulse bits are determined by the amount of propellant decomposed.

Projected response times are rapid. Preliminary tests show that a $170 \mathrm{mg}$ size pellet of the compound decomposes in 7 msec and does not leave any particles. Gas analysis shows that the primary products are $46.5 \% \mathrm{~N}_{2}, 29 \% \mathrm{CO}_{2}$, and $0.5 \% \mathrm{O}_{2}$, with the remaining species $\mathrm{H} 2 \mathrm{O}, \mathrm{H} 2, \mathrm{CO}$, and $\mathrm{CH}_{4}$ not measured.

\section{Mission Trade Studies}

Performance parameters, such as thrust level and specific impulse, often do not fully describe the benefits of a specific propulsion system as applied to a given spacecraft mission. To fully understand the benefit of a new propulsion system, a comparative mission analysis must be performed. As a start in this direction, preliminary evaluations of electrolysis and tridyne $^{\mathrm{m}}$ for selected missions were performed. Advanced monopropellant thrusters fall in the domain of another paper (Ref. 8), and the solid gas generator concept is in too early a stage to warrant inclusion in mission trade studies at this point.

Based on the simple schematics of Figure 2, a weight analysis was obtained for specific mission descriptions. For the missions described in this section, tridyne ${ }^{\mathrm{TM}}$ and electrolysis propulsion are compared to baseline cold gas and state of the art hydrazine monopropellant propulsion systems, respectively. The examples demonstrate that either a decrease in launch mass or an increase in payload mass is achievable with either the electrolysis or tridyne $^{\mathrm{m}}$ concepts, within each of the mission definitions.
Sun-synchronous Picostar Mission

Many satellite manufacturers are offering extremely small spacecraft platforms for customer defined missions. With a dry bus mass of $12.5 \mathrm{~kg}$ and a typical payload capability of $5 \mathrm{~kg}$, the Orbital Sciences Corporation's (OSC) Picostar is an example of such a small spacecraft. The spacecraft can provide approximately 10 watts of power for the payload from its 20 watt solar array and $50 \mathrm{Whr}$ NiCd battery system. Attitude control is provided by active magnetics during its three year lifetime.

Picostar is proposed as a secondary payload for Pegasus. Consequently, the Picostar customer must be satisfied with the primary payload's final orbit, or use an onboard propulsion system to attain the desired orbit. For the mission assumed here, the Landsat spacecraft's $22705 \mathrm{~km}$ circular, 98.2 ${ }^{\circ}$ sun-synchronous operating orbit is arbitrarily assumed as the final orbit. This must be achieved after insertion into a $550 \mathrm{~km}, 97.5^{\circ}$ circular orbit by the Pegasus launch vehicle planned for 1997 . Secondary payload mass and volume are available for this launch. Assuming a mission starting as a secondary payload launched to this orbit, the Picostar is required to change its orbital altitude and inclination to reach its hypothetical $705 \mathrm{~km}, \quad 98.2^{\circ}$ circular operating ortit. Assuming impulsive Hohman transfers for the monopropellant system, the required mission $\Delta V s$ are 62 $\mathrm{m} / \mathrm{s}$ transfer from $550 \mathrm{~km}$ circular @ 97.5 to $550 \mathrm{~km} \times 705 \mathrm{~km} @ 97.84^{\circ}$, and $63 \mathrm{~m} / \mathrm{s}$ transfer from $550 \mathrm{~km} \times 705 \mathrm{~km} @ 97.84^{\circ}$ to $705 \mathrm{~km}$ circular @ 98.2० . Impulsive multiple burn transfers are used for the electrolysis system. This requires approximately the same $\Delta V$. Added to these $\Delta V$ requirements is an assumed $20 \mathrm{~m} / \mathrm{s}$ of orbit correction per year for three years. Thus the total mission $\Delta V$ requirement is $184 \mathrm{~m} / \mathrm{s}$ for each system.

Propulsion systems considered for this mission are state of the art monopropellant and electrolysis systems. Each of the potential propulsion configurations assumes a single thruster mounted along the spacecraft axis. Picostar is controlled using torque coils to control its spin stabilization. It is assumed that the Picostar will be able to point its thrust axis in the appropriate direction to apply the orbit transfer and 
maintenance burns. The impact on the bus subsystems (e.g. thermal and attitude control) of adding a propulsion system to the Picostar should be considered similar for both propulsion system choices and, thus, is not considered here. Multiple burns for the transfer may be necessary depending on the thrust level chosen for the propulsion system.

The required propulsion system wet masses for the SOA monopropellant and electrolysis are shown in Table 3 . The payload and bus mass were set to $5 \mathrm{~kg}$ and $12.5 \mathrm{~kg}$. respectively. Table 3 shows that the electrolysis based propulsion system provides a weight advantage of $1.8 \mathrm{~kg}$ (or $8 \%$ ) over the monopropellant system. The required fuel volume for the electrolysis concept is greatly reduced as compared to monopropellants, although this may be slightly offset by the size of the electrolysis system. Additionally, electrolysis can provide a significant cost savings as the result of less expensive propellant loading and handling procedures.

By using a commercially available $4.48 \mathrm{~N}$ thruster for the monopropellant system, ${ }^{7}$ the bum time is short enough to allow for the orbit transfer of less than a day. This is not the case for the electrolysis system which is limited by the $\mathrm{H}_{2}$ and $\mathrm{O}_{2}$ production rate by the available electrical power. Assuming an input power to the electrolysis unit of $12 \mathrm{~W}$ ( 7 cells), the fuel production rate is $\mathbf{0 . 6 5}$ $\mathrm{mg} / \mathrm{s}$ during the sunlit portion of the orbit. Consequently, the total transfer time for the electrolysis system from $550 \mathrm{~km} \times 550 \mathrm{~km}$ @ $97.5^{\circ}$ to $705 \mathrm{~km} \times 705 \mathrm{~km}$ @ $98.2^{\circ}$ is 22 days.

The possibility exists to replace the standard NiCd battery for this platform with the same electrolysis system working as a fuel cell, in an integrated system. The baseline battery has a battery capacity of $50 \mathrm{Whr} .^{23}$ With the current SOA battery power density of 25 Whr $/ \mathrm{kg}^{24}$ this means that the battery weight is approximately $2 \mathrm{~kg}$. The mission analyzed here consists of approximately 33 minute dark cycle and 65 minutes sun-cycle. A battery replacing fuel cell that provides a capacity of 10 Whrs during the 33 minute dark cycle could provide all housekeeping and payload requirements. The weight of such a fuel cell is approximately $0.8 \mathrm{~kg}$, of which $0.45 \mathrm{~kg}$ is already accounted for in the propulsion system trade off. Replacing the battery, therefore, provides another 1.6 $\mathrm{kg}$ in weight savings, for a total of $3.4 \mathrm{~kg}$ weight savings (or 16\%).

Reliability of electrolysis is projected to be high as the result of long term commercial use of electrolysis devices. ${ }^{17}$ Whether the attractive option to unify the propulsion and power system is used depends mostly on engineering decisions. The integrated unit will be more complex, and will have a conversion efficiency of only $47 \%$. Also, integration of propulsion and power might be seen as a liability for some missions.

\section{ORBCOMM Mission}

Another small satellite launched by the Pegasus is the ORBCOMM spacecraft. Based on the Microstar bus, this vehicle provides low orbit communication service. Two Microstar satellites are already in operation. ORBCOMM is larger than the Picostar both in size and mass (see Table 3). A small gaseous nitrogen $\left(\mathrm{GN}_{2}\right)$ cold gas system is used for initial orbit trimming and spacecraft separation for multiple launches. The required $\Delta V$ capability is reported to be $11 \mathrm{~m} / \mathrm{s}^{23}$ Table 3 shows that replacing the $\mathrm{GN}_{2}$ cold gas system with the tridyne ${ }^{\mathrm{Tn}}$ system cuts the fuel mass and volume by $42 \%$ and $37 \%$, respectively. Tankage for the tridyne $^{\mathrm{TM}}$ system is lighter as the result of the lower fuel mass. This will partly be offset, however, by the presence of a catalyst bed in the tridyne ${ }^{m}$ concept. A reduction of the tridyne ${ }^{\mathrm{TM}}$ system dry mass over cold gas for this mission is still realized. A comparison of both systems for this mission gives an overall weight of 1.3 $\mathrm{kg}$ for the tridyne ${ }^{\mathrm{TM}} \mathrm{vs} .1 .7 \mathrm{~kg}$ for the cold gas, with similar complexity and fuel handling problems. An added advantage of the tridyne ${ }^{\mathrm{Tu}}$ propulsion system, especially for small satellites, is the smaller required volume.

\section{Summary}

An overview is given of propulsion concepts that have potential application for micro satellite propulsion, with thrust levels ranging from $10^{-5}$ to $10 \mathrm{~N}$. Major concepts classification was by the propellant storage phase, i.e. gas, liquid, solid, or hybrid, any combination of the above. 
Four propulsion concepts were analyzed for their applicability to microthrust propulsion: advanced monopropellants, tridyne ${ }^{\pi \mathrm{r}}$, electrolysis, and solid gas generator propulsion. Major factors in the selection process were performance, weight, size, cost, and reliability. Non-toxicity of the propellants used in each of the selected concepts provided an additional benefit in terms of cost savings due to reduced loading and handling problems.

Two of the selected propulsion concepts, tridyne $^{\mathrm{TM}}$ and electrolysis, were compared against currently used propulsion systems, cold gas and state of the art monopropellants. As a potential mission for comparing electrolysis versus state of the art monopropellant systems, an orbital transfer and plane change of an existing microsatellite with subsequent orbit maintenance for three years was analyzed. A tridyne system was compared against a cold gas system for orbit trimming and spacecraft separation of an existing commercial satellite.

Electrolysis propulsion provided a significant weight advantage over state of the art monopropellants for the full mission, 1.6 vs. $2.7 \mathrm{~kg}$ wet mass. Most of the weight advantage was obtained because of higher $l_{\text {sp. }} 350$ vs. 223 , and reduced propellant storage weight. The non-toxicity of the propellants provided an additional benefit. A potential added advantage, which was not fully investigated, was the replacement of the baseline battery system with an integrated electrolysis/fuel cell system for spacecraft power. This could lead to additional weight savings but would significantly increase complexity.

For the mission analyzed for the tridyne ${ }^{7 m}$ and cold gas systems, tridyne ${ }^{\text {ms }}$ provided a significant weight and volume advantage over cold gas thrusters, while retaining the system simplicity. Problems associated with propellant service and handling for both systems are similar.

\section{References}

1. Sutherland, G. S., and Maes, M.E., : "A Review of Microrocket Technology: $1 \sigma^{6}$ to 1 Ibf Thrust," J. Spacecraft and Rockets, Vol. 3, No. 8, August 1966.
2. Myers, R.M., Oleson, S.R., Curran, F.M., and Schneider, S.J.: "Chemical and Electrical Propulsion Options for Small Satellites," Proceedings of the 8th AIAA Utah State University Conference on Small Satellites, Aug. 29-Sept. 1, 1994.

3. Bzibziak, R.:" Miniature Cold Gas Thrusters," AlAA 92-3256, Nashville, July 68, 1992.

4. Barber, H.E., Falkenstein, G.L., Buell, C.A., and Gurnitz, R.N.:" Microthrusters Employing Catalytically Reacted $\mathrm{N}_{2}-\mathrm{O}_{2}-\mathrm{H}_{2}$ Gas Mixtures, Tridyne," J. Spacecraft and Rockets, Vol.8, No. 2, February 1971

5. Schneider, S.J.: " High Temperature Thruster Technology for Spacecraft Propulsion," Acta Astronautica, Vol. 28, pp. 115-125, 1992.

6. Genthe, D. : Attitude Control Systems for Satellites," (In German) Deutsche Forschungs- und Versuchsanstalt fuer Luft- und Raumfahrt, RPT\#: DLR-MITT-70-14, 1970

7. Hydrazine Handbook, Rocket Research Company, Olin Defense Systems Group.

8. Jankovsky, R.S. : " HAN-Based Monopropellant Assessment for Spacecraft," AIAA Paper 96-2863, July, 1996.

9. Kaiser Marquardt data sheets KM Model 53 (9 N thrust), 1995.

10. Hardt, A.P., Foley, W.M., and Brandon, R.L.:" The Chemistry of Subliming Solids for Micro Thrust Engines," Astronautica Acta, Vol. 11, No. 5, 1965.

11. "Development of the Subliming Solid Control Rocket", NASA CR-712, Rocket Research Corporation, Seattle, WA, 1967.

12. Maycock, N., and Pai Verneker, V.R.: - A Photochemical Microrocket for Attitude Control," J. Spacecraft and Rockets, Vol. 6, No. 3, March 1969.

13. Sellers, J.J., Paul, M., Meerman, M., and Wood, R.: " Investigation into Low-Cost Propulsion Systems for Small Satellite Missions." presented at the 9th Annual AIAAUSU Small Satellite Conference, Logan, UT, September 1995. 
14. Wernimont, E.J., and Meyer, S.E.: " Hydrogen Peroxide Hybrid Rocket Engine Performance Investigation," AIAA 94-3147, Indianapolis, IN, June 27-29, 1994.

15. Mueller, J.M., and McFarlane, J.S., " Design of Tridyne Pressurization Systems for Liquid Oxygen/Polybutadiene Hybrid Rocket Motors," AIAA-91-2406, Sacramento, CA, June 24-26, 1991.

16. Thaller, L.H.:" Electrochemistry and Storage," Space Power, NASA Conference Publication 2352, April, 1984.

17. " Unitized Regenerative Fuel Cell Energy Storage Systems for Aircraft and Orbital Applications," Hamilton Standard Space and Sea Systems.

18. Stechman, R.C., Campbell, J.G. "Water Electrolysis Satellite Propulsion System," The Marquandt Company, Technical Report AFRPL-TR-72-132, January, 1973.

19. Reed, B.D. :" Long Life Testing of Oxide-Coated Iridium/Rhenium Rockets," 31st Joint Propulsion Conference, AIAA Paper 95-2401, July, 1995.

20. Hoberecht, M.A., Miller, T.B., Rieker, L.L., and Gonzalez-Sanabria, O.D.:" Design Considerations for a $10 \mathrm{~kW}$ Integrated Hydrogen-Oxygen Regenerative FUEL Cell System," 19th Intersociety Energy Conversion Engineering Conference, San Francisco, CA, Aug. 19-24, 1984.

21. Manser, G., GenCorp. Aerojet, Private Communication.

22. Wilson, A. (Ed.) :Jane's Space Directory 10th Ed., 1994-1995.

23. Meurer, B.: "First Class Science on a Coach Class Ticket," 9th Annual Conf. on Small Satellites, Utah State Univ., Sept. 1995.

24. Tuck, C.D.S. (Ed.) Modern Battery Technology. Ellis-Horwood, New York, pp 279. 


\begin{tabular}{|c|c|c|c|c|c|c|}
\hline \multicolumn{3}{|c|}{ Propulsion Concept } & Propellants & density & Ref & Products (MW) \\
\hline Gas & $\begin{array}{l}\text { Cold Gas } \\
\text { Bipropell. } \\
\text { Tridyne }^{\mathrm{TM}}\end{array}$ & & $\begin{array}{l}\mathrm{N}_{2}(3000 \text { psia }) \\
\mathrm{O}_{2}(3000 \text { psia }) \\
\mathrm{CH}_{4}\left(\mathrm{C}_{2} \mathrm{H}_{4} / \mathrm{H}_{2}\right) \\
\mathrm{H}_{21} \mathrm{O}_{2}, \mathrm{He}, \mathrm{N}_{2} \quad(3000 \\
\text { psia) }\end{array}$ & $\begin{array}{l}0.225 \\
0.257 \\
0.129 \\
0.206\end{array}$ & $\begin{array}{l}1,3 \\
1\end{array}$ & $\begin{array}{l}\mathrm{N}_{2}(28) \\
\mathrm{H}_{2} \mathrm{O}(18), \mathrm{CO}_{2}(44), \\
\mathrm{CO}(28) \\
\mathrm{H}_{2}(2), \mathrm{O}_{2}(32), \mathrm{He}(2)\end{array}$ \\
\hline Liquid & $\begin{array}{l}\text { Vaporiz. } \\
\text { Monopro- } \\
\text { pellants } \\
\text { Bipropell. }\end{array}$ & $\begin{array}{l}\text { gaseous inj } \\
\text { liquid inj. }\end{array}$ & $\begin{array}{l}\text { water }\left(\mathrm{H}_{2} \mathrm{O}\right) \\
\text { ammonia }\left(\mathrm{NH}_{3}\right) \\
\text { Propane }\left(\mathrm{C}_{3} \mathrm{H}_{8}\right) \\
\text { peroxide }\left(\mathrm{H}_{2} \mathrm{O}_{2}\right) \\
\text { hydrazine }\left(\mathrm{N}_{2} \mathrm{H}_{4}\right) \\
\mathrm{ClF}_{3} \\
\text { monomethylamine } \\
\mathrm{N}_{2} \mathrm{O}_{4} / \mathrm{MMH}\end{array}$ & $\begin{array}{l}1.00 \\
0.611 \\
0.585 \\
1.39 \\
1.01 \\
\\
1.77 \\
0.699 \\
1.10 \\
\end{array}$ & $\begin{array}{l}12 \\
6 \\
1 \\
7 \\
\end{array}$ & $\begin{array}{l}\mathrm{H}_{2} \mathrm{O}(18), \mathrm{NH}_{3}(17), \\
\mathrm{C}_{3} \mathrm{H}_{8}(44) \\
\mathrm{H}_{2} \mathrm{O}(28), \mathrm{O}_{2}(32), \\
\mathrm{N}_{2}(28), \mathrm{NH}_{3}(17) \\
\mathrm{C}(12), \mathrm{HF}(19), \\
\mathrm{HCl}(35), \mathrm{H}_{2}(2), \\
\mathrm{N}_{2}(28), \mathrm{CH}_{4}(16) \\
\end{array}$ \\
\hline Solid & Valveless & $\begin{array}{l}\text { Subliming } \\
\text { Photochem } \\
\text { Decompos. }\end{array}$ & $\begin{array}{l}\text { Carbonates }\left(X\left(\mathrm{HCO}_{3}\right)\right) \text {, } \\
\text { Carbamates, } \\
\left(X\left(\mathrm{CO}_{2} \mathrm{NH}_{2}\right)\right) \text {, } \\
\text { SUBLEX-A }(\mathrm{RRC}) \\
\text { Azides }\left(\mathrm{X}\left(\mathrm{HN}_{3}\right)\right) \text {, } \\
\text { Oxalates, } \\
\text { OrganicSolids, } \\
\text { Permanganates, } \\
\text { Perchlorates } \\
\mathrm{C}_{2} \mathrm{H}_{4} \mathrm{~N}_{6} \mathrm{O}_{2} \\
\\
\text { Water }\left(\mathrm{H}_{2} \mathrm{O}\right), \\
\text { Camphor }\left(\mathrm{C}_{10} \mathrm{H}_{16} \mathrm{O}\right) \text {, } \\
\text { Acetamide } \\
\left(\mathrm{CH} \mathrm{H}_{3} \mathrm{CONH} \mathrm{H}_{2}\right) \\
\text { Naphtalene }\left(\mathrm{C}_{10} \mathrm{H}_{8}\right) \text {, } \\
\text { Biphenyl }\left(\mathrm{C}_{12} \mathrm{H}_{10}\right) \\
\end{array}$ & $\begin{array}{l}1.86 \\
\\
1.00 \\
0.990 \\
1.159 \\
1.025 \\
0.8660 \\
\end{array}$ & $\begin{array}{l}9 \\
10\end{array}$ & $\begin{array}{l}\mathrm{NH}_{3}(17), \mathrm{N}_{2}(28) \\
\mathrm{CO}_{2}(44), \\
\mathrm{H}_{2} \mathrm{O}(18) \\
\\
\mathrm{H}_{2}(2), \mathrm{N}_{2}(28), \mathrm{CO}_{2}(44), \\
\mathrm{CO}(28), \mathrm{H}_{2} \mathrm{O}(18) \\
\mathrm{H}_{2} \mathrm{O}(18) \\
\mathrm{C}_{10} \mathrm{H}_{16} \mathrm{O}(152), \\
\mathrm{CH}_{3} \mathrm{CONH} \mathrm{H}_{2}(59), \\
\mathrm{C}_{10} \mathrm{H}_{8}(128) \\
\mathrm{C}_{12} \mathrm{H}_{10}(154)\end{array}$ \\
\hline Hybrid & & & $\begin{array}{l}\text { GOX (3000 psia), } \\
\text { polybutadiene } \\
\left(\left(\mathrm{C}_{4} \mathrm{H}_{6}\right)_{n}\right)\end{array}$ & $\begin{array}{l}0.257 \\
0.97\end{array}$ & $\begin{array}{l}11 \\
12\end{array}$ & $\mathrm{H}_{2} \mathrm{O}(18), \mathrm{CO}_{2}(44)$ \\
\hline $\begin{array}{l}\text { Electro- } \\
\text { chem. }\end{array}$ & Electrol. & & water $\left(\mathrm{H}_{2} \mathrm{O}\right)$ & 1.00 & $\begin{array}{l}15 \\
16\end{array}$ & $\mathrm{H}_{2} \mathrm{O}(18)$ \\
\hline
\end{tabular}

Table 1: Propellant properties of chemical microthruster candidates. 


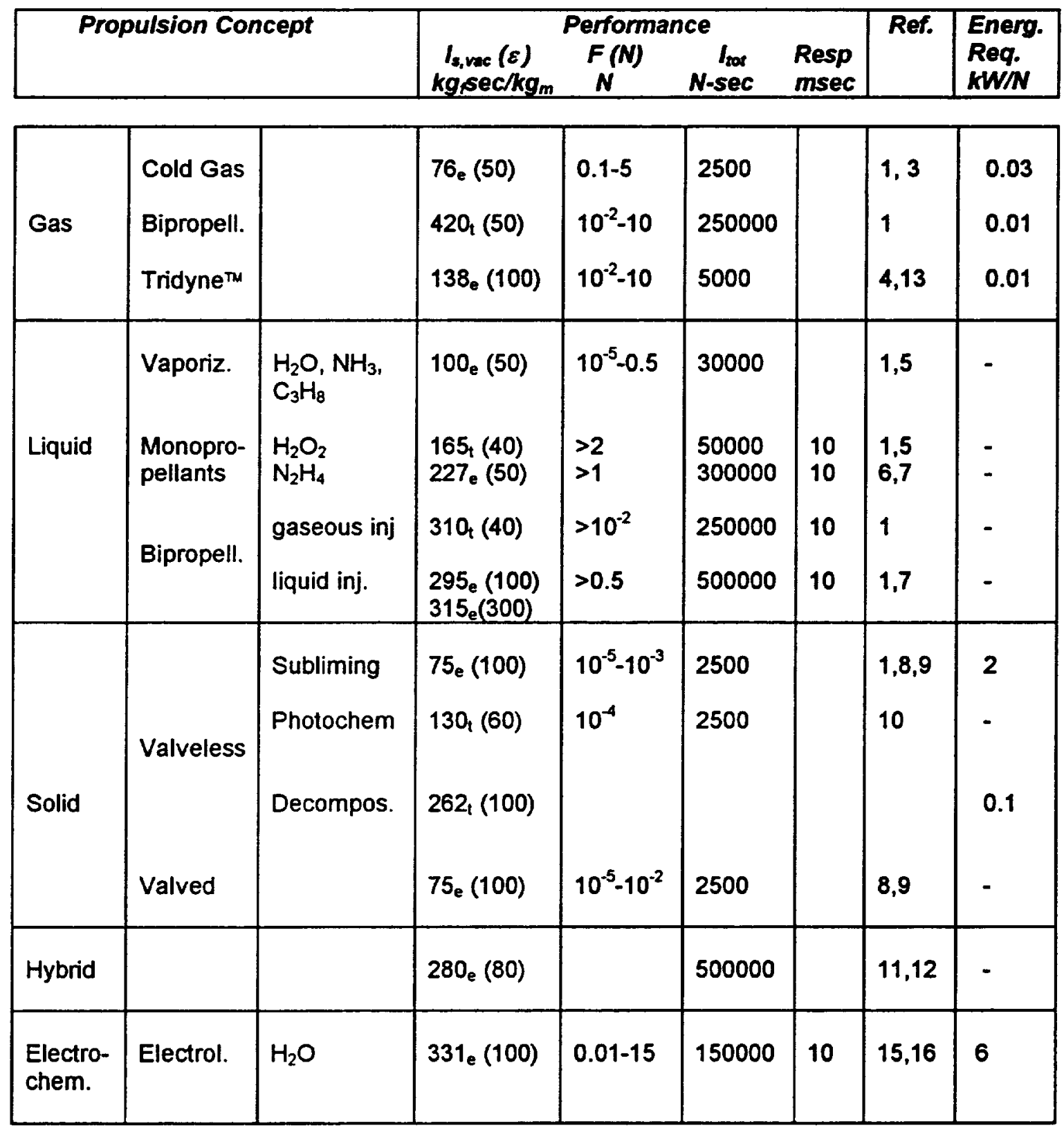

...experimental,...t $=$ theoretical.

Table 2: Performance characteristics of potential chemical microthrusters 


\begin{tabular}{|c|c|c|c|c|}
\hline Mission: & $\begin{array}{r}\text { Picosta } \\
\text { Or } \\
\text { Mai } \\
\end{array}$ & $\begin{array}{l}\text { Landsat } \\
\text { and } \\
\text { nance }\end{array}$ & $\begin{array}{c}\text { ORBCC } \\
\text { Tri }\end{array}$ & $\begin{array}{l}\text { AM Orbit } \\
\text { ning }\end{array}$ \\
\hline Propulsion System & $\begin{array}{l}\mathrm{N}_{2} \mathrm{H}_{4} \\
\text { Monoprop }\end{array}$ & Electrolysis & Cold Gas & Tridyne ${ }^{\text {TM }}$ \\
\hline $\begin{array}{l}\text { Fuel Density }(\mathrm{g} / \mathrm{cc}) \\
\text { Thruster } \Delta \mathrm{V}(\mathrm{m} / \mathrm{s}) \\
\text { Primary Thruster } \mathrm{I}_{\mathrm{sp}}(\mathrm{s}) \\
\text { \# of Thrusters } \\
\text { Initial Mass }(\mathrm{kg}) \\
\text { Cant Angle }\left({ }^{\circ}\right) \\
\text { Fuel Mass }(\mathrm{kg})\end{array}$ & $\begin{array}{l}1.00 \\
184 \\
223 \\
1 \\
22.0 \\
0.0 \\
1.8\end{array}$ & $\begin{array}{l}1.00 \\
184 \\
350 \\
1 \\
20.2 \\
0.0 \\
1.15\end{array}$ & $\begin{array}{l}0.225 \\
11 \\
80 \\
1 \\
43 \\
0.0 \\
0.6\end{array}$ & $\begin{array}{l}0.206 \\
11 \\
138 \\
1 \\
43 \\
0.0 \\
0.35\end{array}$ \\
\hline Propulsion System Dry Mass & 2.68 & 1.6 & 1.08 & 0.94 \\
\hline $\begin{array}{l}\text { Total Fuel Mass } \\
\text { Total Fuel Volume }\left(\mathrm{m}^{3}\right) \\
\text { Total Propulsion Syst. Wet Mass }\end{array}$ & $\begin{array}{l}1.8 \\
0.00178 \\
4.5\end{array}$ & $\begin{array}{l}1.1 \\
0.00107 \\
2.75\end{array}$ & $\begin{array}{l}0.6 \\
0.0027 \\
1.7\end{array}$ & $\begin{array}{l}0.35 \\
0.0017 \\
1.3\end{array}$ \\
\hline $\begin{array}{l}\text { Net Mass (Initial-Wet Prop.) } \\
\text { Spacecraft Internal Vol. }\end{array}$ & $\begin{array}{l}17.5 \\
0.0063\end{array}$ & $\begin{array}{l}17.5 \\
0.0063\end{array}$ & $\begin{array}{l}41.3 \\
0.0014\end{array}$ & $\begin{array}{l}41.65 \\
0.0014\end{array}$ \\
\hline Primary Engine Thrust $(\mathrm{N})$ & 4.45 & 045 & $5.56 \mathrm{~N}$ & $5.56 \mathrm{~N}$ \\
\hline \# Engine Thrusting & 1 & 1 & 2 & 2 \\
\hline Primary Thruster Bum Time (min.) & 15 & 137 & 0.7 & 0.7 \\
\hline
\end{tabular}

Table 3: Picostar Potential Propulsion System Performance Comparison 


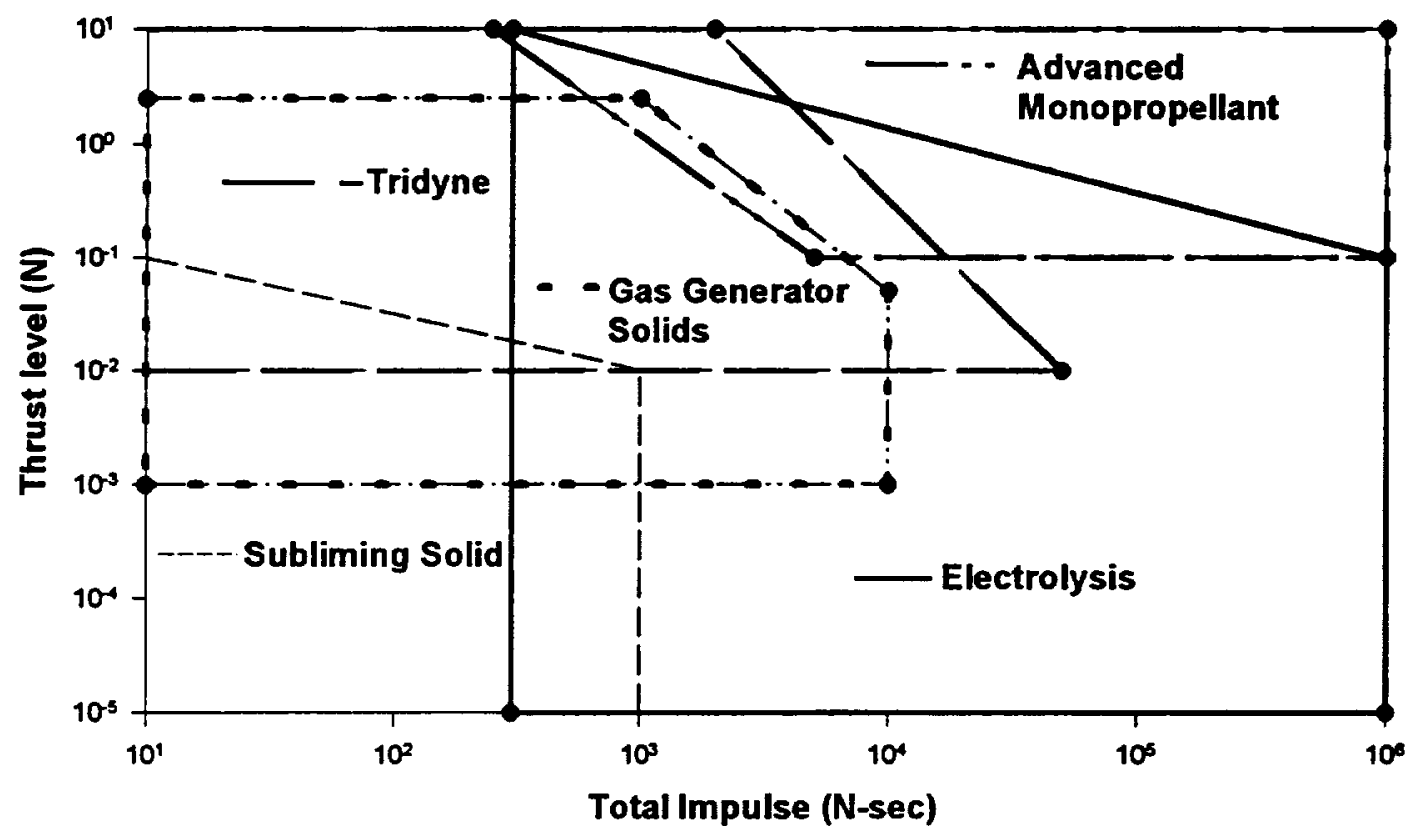

Figure 1: Operating Range of different microthruster concepts

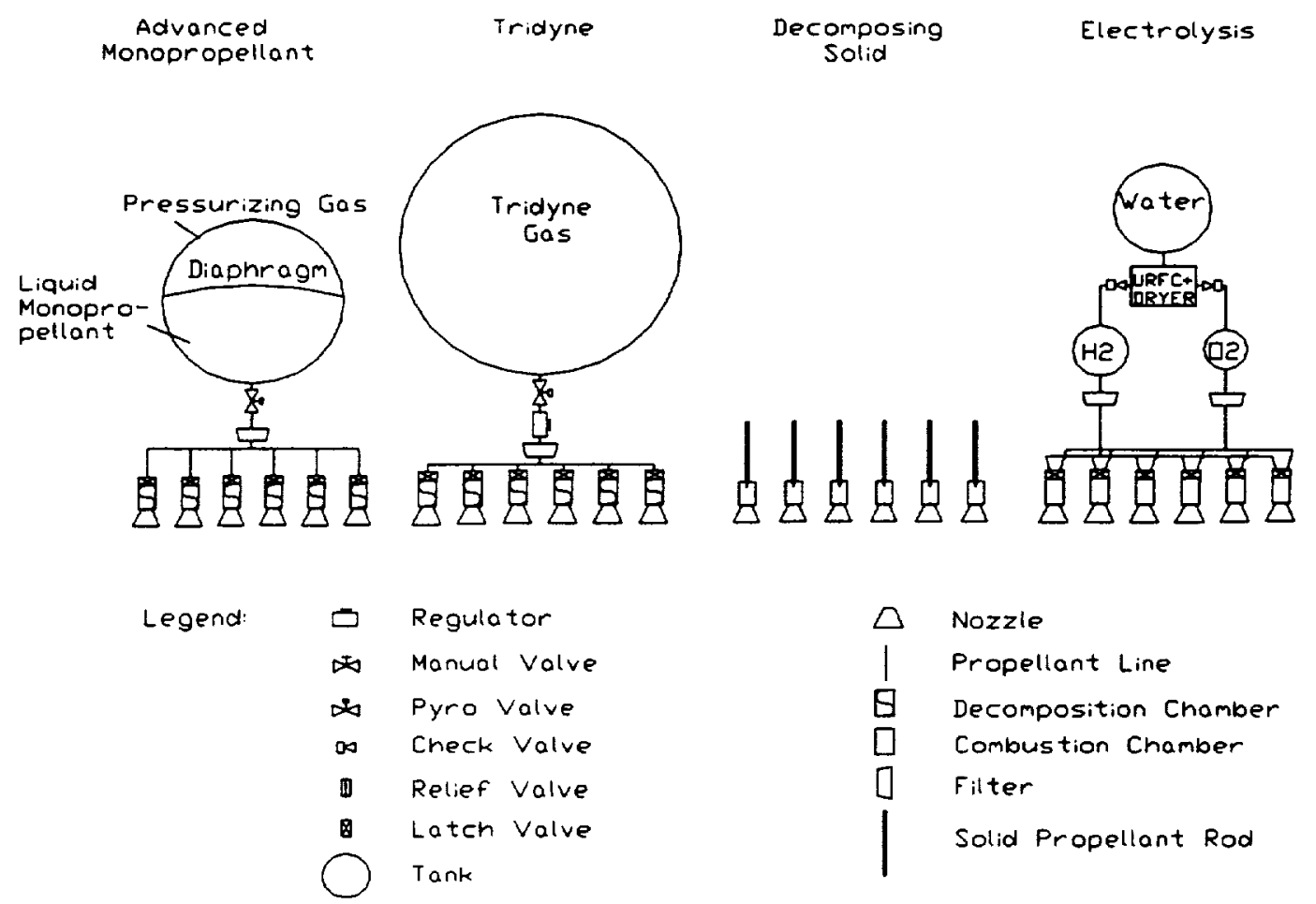

Figure 2: Simple Schematic of four chemical micropropulsion concepts. 

Public reporting burden for this collection of hiformation is estimated to average I hour per response, Including the tirne for reviewing Instructions, searching existing data sources, gathering and maintaining the data needed, and completing and reviewing the collection of information. Send comments regarding this burden estrmate or any other aspect of thi colbetion of intormation, including suggestions for reducing this burden, to Washington Headquarters Services, Directorate lor Intormation Operations and Reports, 1215 Jefterson Davis Highway, Suhe 1204, Arlington, VA $220202-4302$, and to the Otfice of Mansgement and Budget, Papenwork Reduction Project (0704-0188). Washington, DC 20503.

\begin{tabular}{|l|c|c|}
\hline 1. AGENCY USE ONLY (Leave blank) & $\begin{array}{c}\text { 2. REPOAT DATE } \\
\text { October } 1996\end{array}$ & $\begin{array}{r}\text { 3. REPORT TYPE AND DATES COVERED } \\
\text { Final Contractor Report }\end{array}$
\end{tabular}

4. TITE AND SUBTIIE

Chemical Microthruster Options

6. AUTHOA(S)

Wim de Groot and Steve Oleson

7. PERFORMMG ORGANIZATION NAME(S) AND ADDRESS(ES)

NYMA, Inc.

2001 Aerospace Parkway

Brook Park, Ohio 44142

9. SPONSOAINGMONITORING AGENCY NAME(S) AND ADDRESS(ES)

National Aeronautics and Space Administration

Lewis Research Center

Cleveland, Ohio 44135-3191
WU-233-1B-1B

C-NAS3-27186
8. PERFoRIING ORGAMIZATION REPORT NUMBER

E-10445

11. SUPPLEMENTARY NOTES

Prepared for the 32nd Joint Propulsion Conference, cosponsored by AIAA, ASME, SAE and ASEE, Lake Buena Vista, Florida, July 1-3, 1996. Project Manager, Steven J. Schneider, Space Propulsion Technology Division, organization code 5300, (216) 433-7484.

12a. DISTPABUTONAVALABILTY STATEMENT 12b. DISTRIBUTION CODE

Unclassified - Unlimited

Subject Category 20

This publication is available from the NASA Center for AeroSpace Information, (301) 621-0390.

\section{ABSTRACT (Maximum 200 words)}

Chemical propulsion systems with potential application to microsatellites are classified by propellant phase, i.e. gas, liquid or solid. Four promising concepts are selected based on performance, weight, size, cost, and reliability. The selected concepts, in varying stages of development, are advanced monopropellants, tridyne ${ }^{\mathrm{TM}}$, electrolysis, and solid gas generator propulsion. Tridyne ${ }^{\mathrm{TM}}$ and electrolysis propulsion are compared vs. existing cold gas and monopropellant systems for selected microsatellite missions. Electrolysis is shown to provide a significant weight advantage over monopropellant propulsion for an orbit transfer and plane change mission. Tridyne ${ }^{\mathrm{TM}}$ is shown to provide a significant advantage over cold gas thrusters for orbit trimming and spacecraft separation.

14. SUBJECT TERMS

Microthruster; Chemical

17. SECURTY CLASSIFICATION OF REPORT

Unclassified
18. SECURTY CLASSIFICATION OF THIS PAGE

Unclassified
19. SECURTY CLASSIFICATION OF ABSTRACT Unclassified
15. NUMEER OF PAGES

19

16. PAICE CODE

$\mathrm{AO} 3$

20. LIMTTATION OF ABSTRACT 